\title{
ETOS KERJA PEDAGANG MUSLIM SERTA DAMPAKNYA TERHADAP PENINGKATAN KESEJAHTERAAN EKONOMI DI KECAMATAN BIRINGKANAYA KOTA MAKASSAR
}

\author{
Syahidah Rahmah ${ }^{1}$, Rini Sulistiyanti ${ }^{2}$, Hardiyanti Yusuf ${ }^{3}$ \\ ${ }^{1}$ Fakultas Ekonomi dan Bisnis, Universitas Muhammadiyah Makassar \\ email: syahidah_rahmah@unismuh.ac.id \\ ${ }^{2}$ Fakultas Ekonomi dan Bisnis,Universitas Muhammadiyah Makassar \\ email: rinisulistiyantidjafar@gmail.com \\ ${ }^{3}$ Fakultas Ekonomi dan Bisnis Islam, Institut Agama Islam Negeri Palopo \\ email: hardiyanti_yusuf@,iainpalopo.ac.id
}

\begin{abstract}
This study aims to know the work ethic of Muslim Traders in Biringkanaya District, Makassar City in managing their business and know the effect of work ethic on increasing the economic prosperity of Muslim Traders in Biringkanaya District, Makassar City. The type of this study was descriptive quantitative with 30 people of sample using purposive sampling technique and likert scale technique to measure the respondent opinions through the distributed questionnaires. The data analysis techniques of this study included simple linear regression analysis using the SPSS version 23 application by conducting validation and reability tests on the data and classical assumption tests, namely p-plot normality test and multicollinearity test. The results showed that Muslim Traders especially Vegetable Traders and Fish Traders in Biringkanaya District, Makassar City had a high Islamic work ethic in business. The work ethic had a positive and significant impact on increasing the economic prosperity of Muslim Traders in Makassar City.
\end{abstract}

Keywords: Work Ethic, Muslim Traders, Economic Prosperity

\begin{abstract}
ABSTRAK
Penelitian ini dilakukan dengan tujuan untuk mengetahui etos kerja pedagang muslim di kecamatan Biringkanaya Kota Makassar dalam mengelola usahanya serta untuk mengetahui pengaruh etos kerja Islami terhadap peningkatan kesejahteraan pedagang muslim di Kecamatan Biringkanaya Kota Makassar. Jenis penelitian yang digunakan dalam penelitian ini bersifat kuantitatif deskriptif Adapun sampel dalam penelitian sebanyak 30 orang dengan menggunakan teknik purposive sampling. Peneliti mengunakan teknik skala likert untuk mengukur pendapat responden melalui kuisioner yang dibagikan. Adapun teknik analisis data yang digunakan dalam penelitian ini antara lain analisis regresi linier sederhana dengan menggunakan aplikasi SPSS versi 23, dengan terlebih dahulu melakukan uji validasi dan reliabilitas terhadap data yang digunakan serta uji asumsi klasik yaitu uji normalitas p-plot dan uji multikolonieritas. Hasil penelitian menunjukkan bahwa pedagang muslim khususnya pedagang sayur dan pedagang ikan di kecamatan Biringkanaya Kota Makassar memiliki etos kerja Islami yang tinggi dalam menjalankan usahanya. Dan etos kerja Islami berpengaruh positif dan signifikan terhadap peningkatan kesejahteraan ekonomi pedagang muslim di Kota Makassar.
\end{abstract}

Kata Kunci: Etos Kerja, Pedagang Muslim, Kesejahteraan Ekonomi

*Corresponding author. E-mail: syahidah_rahmah@unismuh.ac.id 


\section{PENDAHULUAN}

Islam mendorong umatnya agar bekerja dengan bersungguh-sungguh, bukan menjadi makhluk yang pemalas sehingga memicu terjadinya kemiskinan. Disisi lain, manusia pada dasarnya memang disebut makhluk yang bekerja (homo faber), bahkan manusia dianggap tidak akan mampu memperoleh sesuatu kecuali apa yang telah diusahakannya. Bekerja merupakan salah satu bentuk implementasi yang dianjurkan dalam agama. Bekerja yang dilakukan secara maksimal dalam Islam, tidak hanya mengantarkan seseorang untuk mendapatkan materi namun disisi lain juga akan membawa pada keridhoan Allah atas apa yang dikerjakan.

Etos kerja merupakan totalitas kepribadian diri seseorang dalam bekerja, dengan memberikan pemahaman bahwa etos kerja tidak hanya dicontohkan oleh orang yang bekerja di kantor-kantor dan orang yang memiliki jabatan tinggi, namun etos kerja itu dapat dilakukan dan dikerjakan oleh setiap orang dengan profesi apapun termasuk penjual sayur dan penjual ikan keliling, karena dalam etos kerja ada semangat yang landasi oleh semangat ibadah. Jadi kerja itu tidak hanya sekedar bertujuan untuk memenuhi kebutuhan duniawi saja dalam rangka peningkatan kesejahteraan ekonomi berupa pemenuhan kebutuhan dasar, namun disisi lain juga sebagai bentuk pengabdian manusia sebagai seorang hamba kepada Allah swt demi mendapatkan ridha-Nya atas kerja yang dilakukan.
Bekerja merupakan bentuk pengabdian diri sebagai seorang hamba kepada Allah dengan mentaati segala perintah-Nya dan menjauhi segala larangannya, olehnya itu Allah telah menyediakan fasilitas berupa sumber daya dipermukaan untuk dipergunakan oleh manusia dalam mencapai kesejahteraanya. Etos kerja yang tinggi sangat dibutuhkan dalam melakukan suatu pekerjaan. Mencurahkan segala tenaga dan pikiran atas apa yang dikerjakan akan menghasilkan sesuatu yang baik dan optimal adalah hal yang sangat mendasar dan dianjurkan oleh agama Islam itu sendiri.

Rasullullah telah mempraktikkan etos kerja yang tinggi mulai pada saat beliau masih anak-anak yakni membantu pamannya mennggembala domba, bahkan pada saat remaja beliau sudah berdagang sampai ke negeri Syam yang jaraknya cukup jauh dari kota Mekkah dan bermitra dengan Khadijah sebagai pemiliki modal, dengan etos kerja yang tinggi dan juga ulet beliau menjadikan dagangannya semakin berkembang.

Zaman modern sekarang ini, etos kerja sangat mempengaruhi kebahagiaan dan kesejahteraan ekonomi rumah tangga masyarakat secara umum. Adanya etos kerja yang tinggi dapat memenuhi kebutuhan ekonomi dan keinginan dalam keluarga. Ketika kebutuhan pokok terpenuhi, seperti sandang, pangan, dan papan juga dibutuhkan aspek lain berupa fasilitas yang dapat mendukung keberlanjutan kehidupan itu sendiri seperti fasilitas yang berkaitan dengan rumah tangga, fasilitas yang dapat menunjang status sosial seseorang, juga 
kebutuhan yang sifatnya akan digunakan di masa yang akan datang seperti kebutuhan akan pendidikan anak. Dan untuk memenuhi semua kebutuhan tersebut hanya akan diperoleh etos kerja yang tinggi.

Indonesia yang notabenenya memiliki penduduk muslim terbesar di Asia, memiliki etos kerja yang masih rendah. Hal ini ditandai dengan meningkatnya jumlah pengangguran setiap tahunnya. Berdasarkan data yang diungkapkan oleh Kepala BPS pada hari Senin, 15 Januari 2021 dalam konfrensi pers virtual, bahwa Indonesia memiliki 2,56 juta penduduk yang berstatus pengangguran tahun 2021 .

Sri Hartini dalam jurnalnya berpendapat bahwa lemahnya etos kerja kewirausahaan di kalangan masyarakat Islam disebabkan oleh beberapa faktor budaya. Pertama, tidak ada orientasi kedepan. Orang mengatakan "bagaimana besok" bukan "besok bagaimana". Tidak adanya orientasi ke depan membuat orang segan untuk menabung. Malahan orang memilih untuk berhutang untuk konsumsi atau untuk sesuatu yang belum menjadi miliknya. Kedua, tidak adanya growth philosophy atau kesadaran bahwa segala sesuatu itu harus membesar dan mengakumulasi. Yang paling lemah adalah peningkatan modal atau skala usaha. Seseorang yang mulai jualan bajigur, sering berakhir dengan menjual bajigur juga. Usaha kerap dianggap "memperpanjang hidup" atau "nunut makan". Ketiga, kurang ulet atau "cuek". Orang kerap menyerah bila masalah datang bertubi-tubi. Maka terkenal lah istilah "sudah jatuh dihimpit tangga pula" atau "keluar dari mulut harimau ke mulut buaya". Keempat, retreatism atau berpaling ke akhirat. Kadang ada orang mengatakan "kita miskin di dunia; nanti di akhirat kita masuk surga". Kata para kiai, pendapat seperti itu merupakan pemutarbalikan logika. Amat tidak logis bahwa orang akan masuk surga tanpa usaha apa-apa.

Berdasarkan observasi awal yang dilakukan oleh peneliti kepada beberapa pedagang sayur keliling dan pedagang ikan keliling bahwa disaat manusia yang lain masih tertidur lelap dan sebelum fajar menyingsing, mereka sudah berbondong-bondong pergi ke pasar-pasar tradisional atau mendatangi para pengepul untuk membeli sayursayuran yang nantinya akan mereka jual kembali. Pantang pulang bagi mereka sebelum dagangannya habis terjual atau disaat menjelang malam namun dagangannya belum habis, untuk penjual sayur keliling biasa menjual murah sayur-sayurannya bahkan memberikannya secara cuma-cuma kepada pelanggannya begitupun yang dilakukan oleh penjual ikan keliling. Segelintir orang yang mencontohkan etos kerja yang tinggi ini dikenal dengan pedagang keliling (merchant circle).

Penduduk di Kota Makassar termasuk di Kecamatan Biringkanaya khusunya ibu rumah tangga lebih memilih berbelanja kepada pedagang keliling dalam memenuhi kebutuhan pangannya. Adanya kehadiran pedagang keliling dianggap begitu penting sebagai akibat semakin bergesernya pola hidup masyarakat 
yang semakin lama semakin membutuhkan pelayanan yang instant baik dari segi waktu maupun tenaga. Lokasi pasar Daya yang juga berada di wilayah kecamatan Biringkaya ini, tidak mengendurkan para ibu rumah tangga akan kebutuhannya terhadap eksistensi pedagang keliling ini yang setia membawakan barang kebutuhannya bahkan sampai depan rumah.

\section{KAJIAN LITERATUR}

\subsection{Tinjauan tentang Etos Kerja dalam} Islam

Kerja merupakan segala bentuk usaha yang dilakukan oleh manusia, baik dalam hal materi maupun non-materi, intelektual ataupun fisik maupun hal yang terkait dengan masalah keduniawian ataupun akhirat. Menurut Kamus Besar Bahasa Indonesia, kerja adalah perbuatan melakukan sesuatu dan pekerjaan adalah sesuatu yang dilakukan untuk mencari nafkah.

Menurut Hasan Al-Banna, Islam senantiasa memberikan perhatian kepada setiap orang yang mau berusaha. Islam tidak berharap seseorang itu menganggur, namun Islam justru mengajarkan umatnya untuk bekerja guna memperbaiki bahhkan merubah kondisi ekonomi maupun sosial keluarga. Karena perubahan adalah hasil dari usaha yang dilakukan secara bersungguh-sungguh.

Toto Tasmara dalam bukunya yang berjudul "Membudayakan Etos Kerja Islami" mengatakan bahwa bekerja adalah suatu upaya sungguhsungguh dengan mengerahkan asset, fikir, dan dzikir untuk mengaktualisasikan atau menampakkan arti dirinya sebagai hamba Allah yang harus menundukkan dunia dan menempatkan dirinya sebagai bagian yang terbaik dalam masyarakat.

Dari beberapa pengertian singkat di atas, maka etos kerja merupakan totalitas kepribadian diri, serta cara seseorang berekspresi, memandang, meyakini, dan memberikan sebuah makna, yang mendorong dirinya untuk bertindak dan meraih hasil secara optimal.

Istilah "ethos" berasal dari bahasa Yunani, yang berarti sikap, kepribadian, watak, karakter, serta keyakinan atas sesuatu. Sikap ini tidak saja dimiliki oleh individu, tetapi juga oleh kelompok bahkan masyarakat. Etos dibentuk oleh berbagai kebiasaan, pengaruh budaya, serta sistem nilai yang diyakininya. Dari kata Etos ini, dikenal pula kata etika, etiket yang hampir mendekati pada pengertian akhlak atau nilai-nilai yang berkaitan dengan baik buruk (moral), sehingga dalam etos tersebut terkandung semangat atau gairah untuk mengerjakan sesuatu secara optimal, lebih baik, dan bahkan berupaya untuk mencapai kualitas kerja sesempurna mungkin.

2.2. Kerja, bisnis, dan ibadah

Etos kerja Islam dapat didefenisikan sebagai sikap kepribadian yang melahirkan keyakinan yang sangat mendalam bahwa kerja bekerja itu bukan saja untuk memuliakan dirinya, menampakkan kemanusiaannya, melainkan juga sebagai suatu manifestasi dari amal 
shaleh dan oleh karenanya mempunyai nilai ibadah yang sangat luhur (Moh. Ali Azizi, 2005).

Etos kerja dalam Islam merupakan karakter dan kebiasaan manusia berkenaan dengan kerja, terpancar dari sistem keimanan atau aqidah Islam yang merupakan sikap hidup yang mendasar. (Ahmad Janan Asifuddin, 2004). Olehnya itu, etika dalam bekerja mengandung nilai-nilai dan norma moral.

Selain itu, Effendi menjelaskan dari sisi agama dalam hal ini Islam menyatakan bahwa ada beberapa term yang harus dipahami secara baik yang berkaitan langsung maupun tidak langsung dengan konsep kerja. Term "rizq" misalnya yang sangat erat kaitannya dengan etos kerja. Darmawan Rahardjo dalam bukunya mengulas tentang "rizq", dengan segala variasinya disebutkan dalam Alquran sebanyak 112 kali dalam 41 surah. Begitupun dengan hal yang berkaitan dengan perdagangan (tijarah.

Dalam arti luas, etos kerja berkaitan akan akhlak dalam pekerjaan. Untuk bisa menimbang bagaimana akhlak seseorang dalam bekerja sangat tergantung dari cara melihat arti kerja dalam kehidupannya. Dalam Islam, iman banyak dikaitkan dengan amal, dengan kata lain kerja yang merupakan bagian dari amal tak lepas dari kaitan iman seseorang.

Idealnya, semakin tinggi iman itu maka semangat kerjanya tidak rendah. Ungkapan iman sendiri berkaitan tidak hanya dengan hal-hal spritual tetapi juga program aksi secara tepat guna (Islam dan Ihsan) karena saling terkait dan tidak bisa terpisahkan, bersatu padu dalam kekuatan spritual dan amaliyah.

Bisnis memiliki dua makna berbeda yaitu menurut para mufassir yakni bisnis merupakan kegiatan mengelola modal untuk mendapatkan keuntungan sedangkan menurut ahli fiqih, bisnis adalah menukarkan harta dengan harta secara suka sama suka atau memindahkan hak milik dengan adanya penggantian sesuai dengan cara yang diperbolehkan. Berdasarkan pengertian di atas, maka dapat dipahami bahwa bisnis (perdagangan) yaitu:

1. Bisnis adalah satu bagian muamalah yang berbentuk transaksi antara seseorang dengan orang lain.

2. Transaksi bisnis itu dilakukan dalam bentu $\mathrm{k}$ jual beli yang diwujudkan dalam bentuk ijab dan qabul.

3. Bisnis bertujuan atau dengan motif untuk mencari keuntungan (laba).

Dengan demikian dapat dikatakan bahwa etos kerja untuk pengembangan bisnis Islami harus didasarkan pada niat beribadah karena Allah disamping mencari pengahsilan dengan sungguh-sungguh. Bisnis merupakan salah satu pintu rezeki yang dicontohkan oleh Rasulullah swt, untuk mencaapai ridho Allah swt. Olehnya itu, Rasulullah sangat mengapresiasi bisnis yang dikerjakan dengan tangan sendiri, jerih payah sendiri bukan dari usaha orang lain selama dilandasi dengan sifat kejujuran, adil, dan tidak curang.

Dalam konteks keislaman, etos kerja dalam bisnis akan meningkatkan produktivitas seseorang. 
Karena jika produktivitas dipercaya mempunyai kaitan erat dengan etos kerja, maka etos kerja dipandang terkait dengan nilai-nilai yang dianut oleh seseorang yang memiliki tingkat religiusitas yang tinggi. Menurut salah satu hasil penelitian bahwa diantara nilai yang dianut seseorang yang dianggap sangat dominan mempengaruhi kejiwaan dan sikap seseorang adalah karena nilai-nilai yang berasal dari agama yang dianutnya. Sehingga nilai-nilai ini pulalah yang mengkarakteristikkan etos kerja seseorang.

2.3. Kesejahteraan perpektif Islam

Di Indonesia istilah

kesejahteraan pada umumnya diartikan sebagai terpenuhinya kebutuhan material dan kebutuhan non material dimana manusia aman dan bahagia karena kebutuhan gizi, kesehatan, pendidikan, tempat tinggal, dan pendapatan dapat terpenuhi, serta manakala manusia memperoleh perlindungan dari resiko-resiko utama yang mengancam kehidupannya (Suharto Edi, 2005).

Sebagian pakar berpendapat kesejahteraan yang digambarkan dalam Alquran tercermin dari surga yang dihuni oleh Adam dan Hawa, sesaat sebelum mereka menjalankan tugas mereka sebagai khalifah di muka bumi. Keadaan Adam dan Istrinya di surga bayang-bayang impian manusia akan kehidupan yang nyaman, tercukupinya kebutuhan sandang, pangan dan papan dalam artian tidak lapar, tidak dahaga, tidak telanjang dan kepanasan. Tercukupinya kebutuhan Adam di
Surga merupakan unsur pertama dan utama kesejahteraan sosial.

Kesejahteraan dalam Islam biasa juga disebut falah. Falah merupakan kondisi maksimum yang dirasakan seseorang dalam kebahagiaan di dunia aupun diakhirat. Tercukupinya kebutuhan seseorang, akan memberikan dampak yang disebut maslahah. Maslahah adalah bentuk keadaan baik material maupun non material, yang mampu meningkatkan kedudukan manusia sebagai makhluk yang paling mulia. (P3EI, 2015).

As-Shatibi membagi maslahah ini ke dalam tiga gradasi tingkatan yaitu, kebutuhan dharuriyat (primer), kebutuhan hajiyat (sekunder), dan kebutuhan tahsiniyat (tersier). Dharuriyat yaitu memelihara kebutuhan yang bersifat esensial bagi kehidupan manusia. Kebutuhan pokok itu ada lima yang biasa juga disebut al-Dharuriyatul al-Khams yaitu agama (al-din), jiwa (al-nafs), keturunan (al-nasl), harta (al$m a l)$, dan akal (al-aql). Hajiyat yaitu kebutuhan yang apabila tidak terpenuhi, akan membawa kesulitan bagi manusia. Dan tahsiniyat adalah kebutuhan yang menunjang peningkatan martabat manusia dalam masyarakat dan dihadapan Tuhannya sebagai bentuk kepatuhan (Mardani, 2013). Ketika semua indikator di atas terpenuhi, maka bisa dikatakan seseorang tersebut sudah mencapai kesejahteraan.

Selanjutnya berdasarkan landasan teori dan penelitian terdahulu, maka hipotesis penelitian ini adalah:

1. Pedagang muslim keliling di Kecamatan Biringkanaya Kota 
Makassar memiliki etos kerja yang sangat tinggi.

2. Etos kerja Islami berpengaruh positif signifikan terhadap peningkatan kesejahteraan pedagang muslim di Kecamatan Biringkanaya Kota Makassar.

Pengujian hipotesis dalam model regresi tersebut dilakukan secara parsial yang bertujuan untuk menguji signifikansi pengaruh variabel bebas terhadap variabel terikat. Sehingga, masalah khusus dari pengujian hipotesis dalam model regresi linier sederhana adalah untuk menguji hipotesis, maka hipotesis statistik yang digunakan adalah:

$\mathrm{H}_{0}: \mathrm{b} 1=0$ (Tidak berpengaruh signifikan)

$\mathrm{H}_{1}: \mathrm{b} 1=0$ (Berpengaruh signifikan)

$\mathrm{H}_{0}$ diterima Jika Sig $>\alpha$, berarti variabel bebas tidak berpengaruh signifikan terhadap variabel terikat. Jika Sig $<\alpha$, maka $\mathrm{H}_{1}$ diterima yang berarti bahwa variabel bebas berpengaruh signifikan terhadap variabel terikat.

\section{METODE PENELITIAN}

Jenis penelitian ini merupakan penelitian kuantitatif deskriptif dan mengambil lokasi di Kecamatan Biringkanaya Kota Makassar dengan alasan karena lokasi tersebut mudah dijangkau oleh peneliti.

Menurut Sugiyono (2012), populasi adalah wilayah generalisasi yang terdiri atas objek/subjek yang mempunyai kualitas dan karakteristik tertentu yang ditetapkan peneliti untuk dipelajari dan ditarik kesimpulannya.
Sedangkan menurut Morissan (2012) sampel adalah bagian dari populasi yang mewakili keseluruhan anggota populasi yang sifatnya representatif. Adapun populasi dalam penelitian ini ada seluruh pedagang muslim berjumlah sekitar 200 orang teknik pengambilan sampel menggunakan purposive sampling yakni teknik penentuan sampel berdasarkan pertimbangan tertentu. Menurut Roscoe dalam bukunya Research Methods for Business yang ditulis oleh Sugiyono menyatakan ukuran sampel yang layak adalah antara 30 orang sampai dengan 500 orang, sehingga peneliti hanya mengambil sampel berjumlah 30 orang dengan alasan peneliti tidak mampu menjangkau semuanya. Adapun Sumber Data

- Data primer, adalah data yang diperoleh melalui pengamatan langsung kepada objek penelitian dengan menggunakan kuesioner (angket) serta wawancara langsung kepada para pedagang Muslim yang berjualan keliling di Kecamatan Biringkanaya.

- Data sekunder, adalah data yang diperoleh dari orang lain atau dari dokumen-dokumen pendukung berupa jurnal, serta literatur yang berkaitan dengan apa yang diteliti.

Adapun teknik pengumpulan data yang digunakan yaitu a) Kuesioner merupakan teknik pengumpulan data yang dilakukan dengan cara memberi seperangkat pertanyaan tertulis kepada responden untuk dijawab. Kuesioner ini dianggap efisien bila peneliti tahu dengan pasti variabel apa yang akan diukur dari responden. b) Wawancara 
(interview) dilakukan untuk mengetahui hal-hal dari responden secara mendalam baik bertemu secara langsung maupun menggunakan alat telekomunikasi melalui telpon. c) Observasi. Sutrisno Hadi dalam Sugiyono menejelaskan bahwa observasi merupakan suatu proses yang tersusun dari berbagai proses biologis maupun psikologis dimana dua diantaranya yang penting adalah proses pengamatan dan ingatan.

Teknik analisis data yang digunakan dalam penelitian ini antara lain analisis deskriptif kuantitatif menggunakan uji validitas dan reliabilitas instrumen. Skor yang diperoleh responden kemudian dihitung dan diinterpretasikan ke dalam kriteria sebagai berikut:

Angka 0\%-20\%= Sangat Lemah

Angka 21\% - 40\% = Lemah

Angka 41\% - 60\% = Cukup

Angka $61 \%-80 \%=$ Kuat

Angka 81\% - 100\%= Sangat Kuat

- Uji asumsi klasik yakni uji normalitas dan uji multikolonieritas dan pengujian hipotesis menggunakan model regresi linier sederhana untuk melihat pengaruh antar variabel penelitian.

- Analisis regresi linier sederhana meruapakan alat statistik yang digunakan untuk menentukan hubungan satu prediktor (independen) variabel, dengan satu respon (dependen) variabel. Analisis regresi linier sederhana menghasilkan persamaan sebagai berikut:

Dimana

$$
\mathbf{Y}=\boldsymbol{\alpha}+\boldsymbol{\beta} \mathbf{X}+\mathbf{e}
$$

- Y merupakan variabel dependen

- X merupakan variabel independen

- $\alpha$ merupakan intercape

- $\quad \beta$ merupakan slope

- e merupakan error term

Untuk memudahkan penjelasan sebagai variabel pengaruh (bebas)/ independen menggunakan simbol $\mathrm{X}$ serta variabel terpengaruh (terikat) menggunakan simbol Y. Dalam penelitian ini, variabel bebas (independen) yaitu etos kerja sedangkan variabel terikat (dependen) yaitu peningkatan kesejahteraan ekonomi. Berkaitan dengan hal tersebut, maka untuk mempermudah analisis digunakan program Excel dan SPSS (Statistical Package for Service Solution) versi 24.

\section{HASIL DAN PEMBAHASAN}

Kecamatan Biringkanaya merupakan salah satu kecamatan yang berada di kota Makassar dan memiliki jumlah penduduk dan kepala/keluarga terbesar dengan jumlah 208.436 orang (BPS Statistik, 2019). Pekerjaan menjual sayur dan ikan keliling merupakan salah satu pekerjaan dalam sektor informal do daerah ini yang tidak membutuhkan kualifikasi pendidikan tertentu maupun seleksi bagi yang ingin bekerja. Umumnya pedagang sayur dan pedagang ikan keliling ini menjual dari rumah ke rumah dengan cara membonceng barang dagangannya dan biasanya dilakukan oleh kaum pria yang sudah berkeluarga demi memenuhi kebutuhan ekonomi keluarga dalam rangka mencapai kesejahteraan termasuk dari sisi ekonomi.

1. Deskripsi Responden

a. Jenis Kelamin 
Jenis kelamin pedagang ikan dan sayur keliling di kecamatan Biringkanaya Kota Makassar dapat dilihat dari table berikut:

Tabel. 1 Deskripsi Jenis Kelamin

\begin{tabular}{|c|c|c|}
\hline $\begin{array}{c}\text { Jenis } \\
\text { Kelamin }\end{array}$ & $\begin{array}{c}\text { Frekuensi } \\
\text { (orang) }\end{array}$ & $\begin{array}{c}\text { Persentase } \\
(\mathbf{\%})\end{array}$ \\
\hline Laki-Laki & 28 & $93,3 \%$ \\
\hline Perempuan & 2 & $6,6 \%$ \\
\hline Total & $\mathbf{3 0}$ & $\mathbf{1 0 0}$ \\
\hline
\end{tabular}

Sumber: Data diolah, 2021

Dari tabel di atas dapat dikemukakan bahwa mayoritas pedagang sayur dan pedagang ikan keliling mayoritas dilakukan oleh lakilaki. Hal ini disebabkan karena berjualan keliling adalah pekerjaan yang memerlukan tenaga atau menggunakan fisik. Berdasarkan wawancara singkat. bahwa pedagang ini sepenuhnya menyadari akan kewajiban dan tanggung jawab mereka sebagai kepala keluarga.

\section{b. Umur}

Umur dari responden pedagang ikan dan sayur keliling di kecamatan Biringkanaya Kota Makassar dapat dilihat dari table berikut:

Tabel. 2. Deskripsi Usia Responden

\begin{tabular}{|c|c|c|}
\hline Usia & $\begin{array}{c}\text { Frekuensi } \\
\text { (Orang) }\end{array}$ & $\begin{array}{c}\text { Persentase } \\
(\mathbf{\%})\end{array}$ \\
\hline $21-30$ tahun & 22 & $73,3 \%$ \\
\hline $31-40$ tahun & 6 & $20 \%$ \\
\hline$>40$ tahun & 2 & $6,7 \%$ \\
\hline Total & $\mathbf{3 0}$ & $\mathbf{1 0 0}$ \\
\hline
\end{tabular}

Sumber: Data diolah, 2021

Dari tabel di atas dapat disimpulan bahwa yang menjadi responden dalam penelitian ini lebih banyak yang berumur 36-40 tahun. Hal ini dikarenakan usia 21-30 tahun masuk dalam kategori usia produktif dan memiliki daya tahan kerja yang masih tinggi sehingga memperlijhatkan etois kerja yang baik pula.

c. Lama Berdagang

Lama berdagan dari responden pedagang ikan dan sayur keliling di kecamatan Biringkanaya Kota Makassar dapat dilihat dari table berikut:

Tabel. 3. Deskripsi Lama Berdagang

\begin{tabular}{|c|c|c|}
\hline $\begin{array}{c}\text { Lama } \\
\text { Berdagang }\end{array}$ & $\begin{array}{c}\text { Frekuensi } \\
\text { (Orang) }\end{array}$ & $\begin{array}{c}\text { Persentase } \\
(\mathbf{\%})\end{array}$ \\
\hline $5-10$ tahun & 13 & $43,3 \%$ \\
\hline 11-20 tahun & 17 & $56,6 \%$ \\
\hline Total & $\mathbf{3 0}$ & $\mathbf{1 0 0}$ \\
\hline
\end{tabular}

Sumber: Data diolah, 2021

Dari tabel di atas dapat disimpulkan bahwa lama berdagang paling banyak berada dikisaran 11-20 tahun. Hal ini menunjukkan bahwa lama berdagang memberikan gambaran mengenai pola pemikiran, perilaku, pengalaman, dan tingkat keterampilan pedagang dalam melakukan usahanya. Sehingga semakin lama pedagang itu berdagang maka semakin baik pula etos kerjanya.

\subsection{Uji Instrument}

Variabel dalam penelitian ini dikelompokkan menjadi dua yaitu etos kerja Islami pedagang yang terdiri dari pedagang sayur dan pedagang ikan keliling (X) dan peningkatan kesejahteraan ekonomi (Y) dengan $\mathrm{R}$ table 0.361 . Berdasarkan uji validitas terhadap item-item pernyataan yang digunakan, dapat dilihat table berikut: 
Tabel. 4. Hasil Uji Validitas Variabel X

\begin{tabular}{|c|c|c|c|}
\hline $\begin{array}{c}\text { Variabel } \\
\mathbf{X}\end{array}$ & $\begin{array}{c}\text { Nilai } \\
\mathbf{R} \\
\text { hitung }\end{array}$ & $\begin{array}{c}\text { Nilai } \mathbf{R} \\
\text { Tabel }\end{array}$ & Keputusan \\
\hline P1 & 0,541 & 0,361 & Valid \\
\hline P2 & 0,444 & 0,361 & Valid \\
\hline P3 & 0,196 & 0,361 & Tidak Valid \\
\hline P4 & 0,304 & 0,361 & Tidak Valid \\
\hline P5 & 0,652 & 0,361 & Valid \\
\hline P6 & 0,416 & 0,361 & Valid \\
\hline P7 & 0,535 & 0,361 & Valid \\
\hline P8 & 0,810 & 0,361 & Valid \\
\hline P9 & 0,810 & 0,361 & Valid \\
\hline P10 & 0,810 & 0,361 & Valid \\
\hline
\end{tabular}

Sumber: Data diolah, 2021

Berdasarkan hasil perhitungan uji validitas variabel $\mathrm{X}$ terhadap 30 responden, dikatakan bahwa dari 10 item pernyataan, ada 2 item yang tidak valid. Sehingga item pernyataan tersebut harus dikeluarkan atau dihilangkan. Hal ini ditunjukkan bahwa nilai $\mathrm{R}$ hitung lebih besar dari $\mathrm{R}$ table.

Tabel. 5. Hasil Uji Validitas Variabel Y

\begin{tabular}{|c|c|c|c|}
\hline $\begin{array}{c}\text { Variabel } \\
\text { Y }\end{array}$ & $\begin{array}{c}\text { Nilai } \\
\mathbf{R} \\
\text { hitung }\end{array}$ & $\begin{array}{c}\text { Nilai } \\
\mathbf{R} \\
\text { Tabel }\end{array}$ & Keputusan \\
\hline P1 & 0,389 & 0,361 & Valid \\
\hline P2 & 0,811 & 0,361 & Valid \\
\hline P3 & 0,812 & 0,361 & Valid \\
\hline P4 & 0,767 & 0,361 & Valid \\
\hline P5 & 0,702 & 0,361 & Valid \\
\hline P6 & 0,419 & 0,361 & Valid \\
\hline P7 & 0,477 & 0,361 & Valid \\
\hline
\end{tabular}

Sumber: Data diolah, 2021

Berdasarkan hasil perhitungan uji validitas variabel $\mathrm{Y}$ terhadap 30 responden, dikatakan bahwa dari 7 item pernyataan semua dinyatakan valid. Hal ini ditunjukkan bahwa nilai $\mathrm{R}$ hitung lebih besar dari $\mathrm{R}$ table, sehingga dapat dilakukan penelitian lebih lanjut.

b. Uji Reliabilitas

Tabel 6. Hasil Uji Reliabilitas

Sumber: Data diolah, 2021

Hasil pengujian reliabilitas data

\begin{tabular}{|c|c|c|}
\hline Variabel & $\begin{array}{c}\text { Cronbach's } \\
\text { Alpha }\end{array}$ & Keterangan \\
\hline $\begin{array}{c}\text { Etos Kerja } \\
\text { Islami } \\
\text { Pedagang } \\
\text { Muslim (X) }\end{array}$ & 1,000 & Reliabel \\
\hline $\begin{array}{c}\text { Peningkatan } \\
\text { Kesejahteraan }\end{array}$ & 0,986 & Reliabel \\
\hline
\end{tabular}

yang dilakukan di atas, menunjukkan bahwa dari semua variabel yang diteliti dapat dikatakan reliabel karena nilai koefisien Cronbach alpha yang dihasilkan lebih besar dari nilai 0,6. Semakin besar nilai Cronbach alpha berarti instrumen tersebut semakin reliabel atau handal.

\section{c. Uji Asumsi Klasik}

Uji normalitas bertujuan untuk menguji apakah dalam model regresi, variabel dependen dan independen keduanya mempunyai distribusi normal atau tidak. Untuk lebih memperjelas tentang sebaran data dalam penelitian ini maka akan disajikan dalam grafik histogram dan grafik normal P-Plot. Jika sumbu menyebar sekitar garis diagonal atau grafik histogramnya menunjukkan pola distribusi normal, maka model regersi memenuhi asumsi normalitas. Jika data menyebar jauh dari garis diagonal atau tidak mengikuti arah garis diagonal atau grafik histogram tidak menunjukkan pola 
distribusi normal, maka model regresi tidak memenuhi asumsi normalitas.

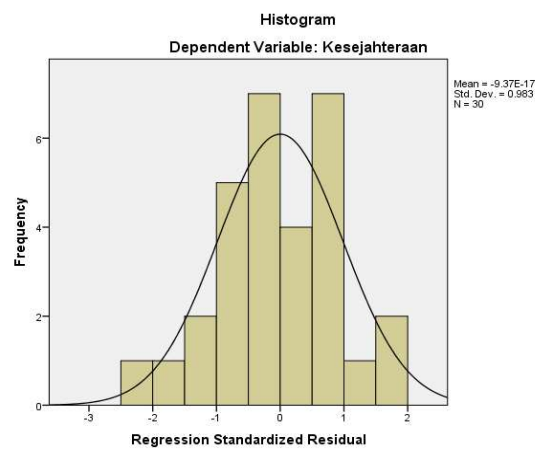

Gambar 1. Grafik Histogram

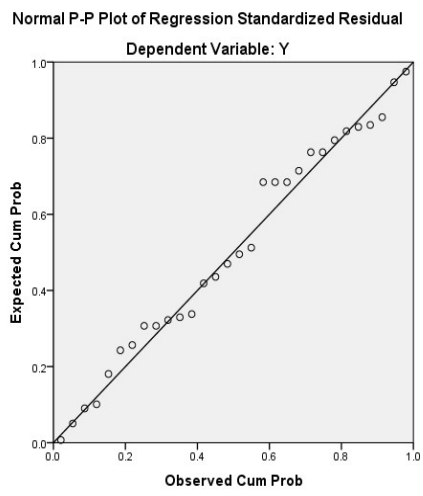

Gambar 2. Grafik P-Plot

\begin{tabular}{lccr}
\multicolumn{2}{c}{ Dengan } & melihat tampilan \\
grafik & histogram & maupun & grafik \\
normal & P-Plot & diatas & dapat
\end{tabular} disimpulakan bahwa grafik histogram memberikan pola distribusi yang mendekati normal. Sedangkan pada grafik normal P-Plot terlihat titik-titik menyebar disekitar garis diagonal, serta arah penyebarannya mengikuti arah garis diagonal sehingga menunjukkan pola distribusi normal. Kedua grafik tersebut menunjukkan bahwa model regresi layak dipakai karena memenuhi asumsi normalitas.
Uji multikolinieritas berasal dari hasil perhitungan yang ada pada uji multikolonearitas, yakni variabel bebas menunjukaan bahwa niai VIF $=$ 1 dimana nilai tersibut lebih kecil dari 10 , sehingga dapat disimpulkan bebas dari multikolonieritas.

\section{d. Uji Hipotesis}

1. Etos Kerja Islami

Etos kerja Islami merupakan sikap atau pandangan mendasar yang diyakini seorang muslim bahwa bekerja tidak hanya mememuliahkan diri tetapi juga sebagai suatu manifestasi dari amal shaleh dan mempunyai nilai ibadah dimata Allah Swt.

distribusi frekuensi tanggapan responden tentang etos kerja Islami secara deskriptif termasuk dalam kategori tinggi. Hal ini dilihat dari rata-rata jumlah jawaban responden terhadap item pernyataan adalah 140 atau sebesar $71,43 \%$. Jika nilai atau skor berada dikisaran $61 \%-80 \%$, ini menunjukkan bahwa etos kerja para pedagang berada pada kriteria tinggi, sehingga bisa dakatakan bahwa pedagang muslim di kecamatan Biringkanaya Kota Makassar memiliki etos kerja yang tinggi dalam bekerja. 
2. Hasil Uji Regresi Linier Sederhana

Tabel 6. Hasil Uji Linier Sederhana

Berdasarkan hasil pengelolaan data

\section{Coefficients $^{\mathrm{a}}$}

\begin{tabular}{|c|c|c|c|c|c|}
\hline \multirow[b]{2}{*}{ Model } & \multicolumn{2}{|c|}{$\begin{array}{l}\text { Unstandardi } \\
\text { zed } \\
\text { Coefficients }\end{array}$} & $\begin{array}{c}\text { Standardiz } \\
\text { ed } \\
\text { Coefficien } \\
\text { ts }\end{array}$ & & \\
\hline & B & $\begin{array}{l}\text { Std. } \\
\text { Error }\end{array}$ & Beta & $\mathrm{t}$ & Sig. \\
\hline $\begin{array}{l}\text { (Consta } \\
\mathrm{nt})\end{array}$ & 8.817 & $\begin{array}{r}9.00 \\
7\end{array}$ & & .979 & .336 \\
\hline $\begin{array}{l}\text { Etos } \\
\text { Kerja }\end{array}$ & .409 & .123 & .715 & $\begin{array}{r}2.12 \\
3\end{array}$ & .042 \\
\hline
\end{tabular}

a. Dependent

Variable: Peningkatan

Kesejahteraan

Sumber: Data diolah, 2021

SPSS maka didapatkan hasil persamaan regresi sebagai berikut:

$$
\begin{aligned}
& Y=b_{0}+b_{1} X_{1} \\
& Y=8.817+0,409 X
\end{aligned}
$$

Dari persamaan regresi diatas, maka terlihat bahwa etos kerja Islami yang dimiliki pedagang muslim bertanda nilai positif, yang memberikan gambaran adanya peningkatan kesejahteraan pedagang muslim yang berjualan di Kecamatan Biringkanaya Kota Makassar. Dimana jika etos kerja pedagang muslim naik maka kesejahteraan pedagang muslim juga naik.

Selanjutnya dari tabel diatas juga menujukkan bahwa etos kerja memberikan pengaruh yang signifikan terhadap peningkatan kesejahteraan dimana signifikansi mempunyai nilai $0,042<0,05$, ini memberikan arti bahwa etos kerja Islami secara statistik berpengaruf signifikan terhadap peningkatan kesejahteraan ekonomi pedagang di kecamatan Biringkanaya Kota Makassar. Sehingga hasil ini menyimpulkan bahwa hipotesis alternatif $\mathrm{H}_{1}$ diterima .

\section{Analisis Koefisien Penentu} (Determinasi)

Analisis koefisien penentu dilakukan untuk melihat seberapa besar kontribusi etos kerja Islami mempengaruhi tingkat kesejahteraan pedagang muslim di Kecamatan Biringkanaya Kota Makassar. Dengan menggunakan SPSS diperoleh output sebagai berikut:

\section{Tabel 7. Koefisien Determinasi}

\begin{tabular}{|l|c|r|r|r|}
\hline Model & $\mathrm{R}$ & $\begin{array}{c}\mathrm{R} \\
\text { Square }\end{array}$ & $\begin{array}{l}\text { Adjusted R } \\
\text { Square }\end{array}$ & $\begin{array}{c}\text { Std. Error of } \\
\text { the Estimate }\end{array}$ \\
\hline 1 & .374 & .140 & .109 & 2.528 \\
\hline
\end{tabular}
a. Predictors: (Constant), Etos Kerja
b. Dependent Variable: Peningkatan
Kesejahteraan

Sumber: Data diolah, 2021

Berdasarkan hasil analisis SPSS di atas, koefisien korelasi dalam perhitungan adalah sebesar 0,374. Ini mengambarkan bahwa korelasi atau hubungan antara variabel terikat dengan variabel bebas bernilai positif. Dimana hubungan yang positif artinya 
jika etos kerja Islami meningkat maka kesejahteraan pedagang muslim di Kecamatan Biringkanaya Kota Makassar juga akan meningkat. Dan hubungan antara variabel bebas dan variabel terikat sebesar 37,4\%.

Koefisein determinasi $\left(\mathrm{R}^{2} / \mathrm{R}\right.$ Square) atau koefisien penentunya sebesar 0,140 . Hal ini menggambarkan bahwa $14 \%$ variasi naik turunnya variabel terikat ditentukan oleh variabel bebas. Artinya naik turunnya kesejahteraan pedagang muslim dipengaruhi oleh etos kerja islami sebesar $14 \%$ sedangkan sisanya $86 \%$ dijelaskan oleh faktor-faktor lain.

1. Etos Kerja Pedagang Muslim

Hasil penelitian ini menunjukkan bahwa pedagang muslim di Kecamatan Biringkanaya Kota Makassar memiliki etos kerja yang tinggi sesuai skor rata-rata dari item pernyataan sebesar $71,43 \%$. Jika nilai atau skor berada dikisaran $61 \%$ - 80\% maka dapat dikatakan tinggi. Namun ini tidak memiliki pengaruh yang begitu besar dilihat dari koefisien determinasi sebesar 37,4 $\%$.

Menutur Sairin, peningkatan etos kerja masyarakat dapat dilakukan dengan mengambil nilai kerja keras dari agama. Setiap agama yang dianut oleh masyarakat Indonesia mengajarkan kepada penganutnya untuk bekerja keras dalam hidup dan kerja keras di dunia merupakan bagian dari ibadah. Hasil kerja keras itu dengan sendirinya akan mendorong pelaksanaan ibadah. Keuletan dan kerja keras merupakan pantulan dari seseorang yang taat menjalankan perintah agamanya. Dalam agama Islam dinyatakan bahwa usaha ulet dan kerja keras merupakan tanggung jawab langsung kepada Tuhan. Jadi kesadaran beragama mempunyai potensi sebagai pendorong yang sedikit banyak menyangkut kegiatan sosial ekonomi.

Tidak terlepas dari pengamalan ajaran Islam sebagai perwujudan seorang muslim yang taat serta bertanggung jawab, para pedagang keliling ini diharapkan mampu memberi manfaat dimana konsumen akan kembali membeli barang jualannya. Sikap ini akan mendorong perkembangan ekonomi masyarakat. Para pedagang yang dijadikan sumber dalam penelitian ini kesemuanya beragama Islam yang taat, mereka dalam menjalankan usahanya berpegang pada ajaran agama sehingga semangat atau etos kerja yang mereka tampilkan tidak bisa terlepas dari substansi ajaran Islam yang diwujudkan dalam kegiatan ekonomi.

Rasulullah sendiri merupakan pebisnis sukses dan letak kunci kesuksesan beliau adalah etos kerjanya yang tinggi. Rasulullah mulai berdagang secara mandiri sejak beliau berusia 17 tahun sampai 37 tahun. Dan etos kerja keras beliau tidak berhenti saat beliau menikah dengan Khadijah pada usia 25 tahun. Rasulullah tetap melanjutkan jiwa kewirausahaannya dengan menjadi manajer sekaligus mitra dalam usaha istrinya. Walaupun tidak ada catatan 
konkret tentang jenis usaha apa yang digeluti oleh beliau selama periode tersebut, banyak indikasi tentang adanya hubungan dagang beliau dengan sejumlah pihak. Hal ini menunjukkan bahwa beliau memang serius dalam menekuni bisnis dan menganjurkan umatnya untuk juga mengikuti langkah beliau untuk menjadi individu yang rajin bekerja dan berusaha.

Ada beberapa prinsip dan konsep yang melatarbelakangi keberhasilan Rasulullah saw dalam bisnis, prinsip-prinsip itu intinya merupakan fundamental Human Etic atau sikap-sikap dasar manusiawi yang menunjang keberhasilan seseorang. Prinsip-prinsip bisnis Rasulullah saw adalah sebagai berikut:

1. Shiddiq, nilai dasarnya ialah integritas dan nilai-nilai dalam bisnisnya berupa jujur, ikhlas, terjamin, dan keseimbangan emosional.

2. Amanah, nilai dasarnya terpercaya dan nilai-nilai dalam berbisnisnya ialah adalah kepercayaan, bertanggung jawab, transparan dan tepat waktu.

3. Fathanah, nilai dasarnya ialah memiliki pengetahuan yang luas dan nilai bisnisnya adalah memiliki visi, pemimpin yang cerdas, sadar produk dan jasa, serta belajar berkelanjutan.

4. Tabligh, nilai dasarnya ialah komunikatif dan nilai bisnisnya ialah supel, penjual yang cerdas, deskripsi tugas, delegasi wewenang dan kordinasi.

5. Syafa'ah, nilai dasarnya ialah berani, mau dan mampu mengambil keputusan, menganalisis data, keputusan yang tepat cepat tanggap.

Kelima sifat dasar ini mempengaruhi Rasulullah dalam berbisnis, sehingga dapat membawa sukses dalam berbisnis, agar bisnis yang digeluti dapat berkembang dengan baik.

Selain faktor agama, etos juga merupakan bagian yang tidak terpisahkan dari sistem kebudayaan. Sebagai watak dasar suatu masyarakat, etos berakar dalam kebudayaan masyarakat itu sendiri. Kebudayaan sebagai suatu sistem gagasan yang dimiliki suatu masyarakat dari proses belajar, adalah induk etos itu. Oleh karena itu, setiap masyarakat dan kebudayaan mempunyai etos yang berbeda-beda termasuk dalam hubungannya dengan etos kerja. Adanya budaya Siri' na pacce' dalam masyarakat Sulawesi Selatan (Bugis, Makassar, Toraja, dan Mandar) sangat dijunjung tinggi sebagai falsafah dalam segala aspek kehidupan. Falsafah Siri na pacce merupakan suatu konsep tentang kehormatan dan rasa malu. Wiraswasta masyarakat Sulawesi Selatan sudah terkenal sejak dahulu sebagai seorang yang berani mengambil resiko, ulet dan percaya diri adalah suatu etos yang berakar dalam kebudayaan masyarakat sikap kompetitif dalam memperebutkan 
asset sosial, biasanya merupakan refleksi dari budaya siri' na pacce itu sendiri.

2. Pengaruh Etos Kerja Islami dalam Peningkatan Kesejahteraan Ekonomi $\begin{array}{lrr}\text { Menurut } & \text { Bagus } & \text { Ramadhan, } \\ \text { pedagang yang r selalu } & \text { nilai-nilai } \\ \text { mengimplementasikan }\end{array}$ etos kerja Islami akan selalu berupaya bekerja dengan lebih baik bukan hanya pasrah dengan keadaan tetapi justru dengan segala kendala, permasalahan, dan tantangan yang ada menjadi dorongan semangat sebagai pemancing kreatifitas, membentuk pribadi yang tangguh dan tidak pantang menyerah, pandai melihat peluang, mengoptimalkan waktu dengan tetap menjaga komitmen kepada Allah SWT, keluarga, masyarakat dan dirinya sendiri untuk tetap istiqamah pada jalan yang benar sehingga memiliki moralitas yang bersih dan berdampak pada kinerja bisnis pedagang itu sendiri.

Menurut Qardhawi, bahwa agama Islam memandang bekerja adalah bagian dari ibadah dan jihad jika sang pekerja bersikap konsisten terhadap peraturan Allah SWT, suci niatnya dan tidak melupakan-Nya. Dengan bekerja, masyarakat bisa melaksanakan tugas kekhalifahannya, menjaga diri dari maksiat, dan meraih tujuan yang lebih besar. Berdasar cara pandang agama Islam tergambar bahwa orientasi kinerja tidak hanya untuk memaksimalkan laba semata seperti penggunaan pada metode penilaian kinerja konvensional, tetapi orientasi kinerja perlu meliputi dimensi yang lebih luas dan menyeluruh, yakni kesejahteraan para stakeholder meliputi investor, karyawan, pelanggan, pemasok, komunitas, lingkungan/sosial.

\section{KESIMPULAN}

1. Pedagang muslim khususnya pedagang sayur dan pedagang ikan di kecamatan Biringkanaya Kota Makassar memiliki etos kerja Islami yang tinggi dalam menjalankan usahanya.

2. Etos kerja Islami berpengaruh positif dan signifikan terhadap peningkatan kesejahteraan ekonomi pedagang muslim di Kota Makassar. 


\section{DAFTAR PUSTAKA}

Asifudin, Ahmad Janan. (2004). Etos Kerja Islam. Surakarta: Muhammadiyah University Press.

Azizi, Moh Ali. (2005). Dakwah Pemberdayaan Masyarakat Paradigma Aksi Metodologi. Yogyakarta: Pustaka Pesantren.

Edi, Suharto. (2005). Membangun Masyarakat Memberdayakan Rakyat: Kajian Strategis Pembangunan

Kesejahteraan Sosial dan Pekerjaan Sosial. Bandung: PT.Refika Aditama.

Fuaddi, Husni. (2018). Etos Kerja Dalam Prspektif Islam. Jurnal Al-Amwal, Vol. 7, No. 1, Juni 2018. 20-30.

Hamid, Abu, dkk. (2003). Siri dan Passe; Harga Diri Manusia Bugis. Makassar: Pustaka Refleksi.

Mardani. (2013). Ushul Fiqh. Jakarta: Raja Grafindo Persada.

Morissan. (2012). Metode Penelitian Survei. Edisi.1; Cet.1; Jakarta: Kencana.

Mufid, Moh. (2018). Maqasid Ekonomi Syariah; Tujuan dan Aplikasi. Malang: Empatdua Media.

Muhammad. (2019). Sistem Keuangan Islam; Prinsip dan Operasionalnya di
Indonesia. Jakarta: Rajwali Pers

Priyanto, Duwi. (2009). SPSS :Untuk Analisis Korelasi, Regresi, dan Multivariate. Yogyakarta: Gava Media, 2009.

Prasetyo, Bambang dan Lina Miftahul Jamal. (2008). Metode Kuantitatif: Teori dan Aplikasi. Cet. IV; Jakarta: PT.Raja Grafindo Persada.

Pusat Pengkajian dan Pengembangan Ekonomi Islam (P3EI). (2015). Ekonomi Islam. Jakarta: Rajawali Pers.

Riduwan. (2010). Belajar Mudah Penelitian Untuk Guru Karyawan dan Peneliti Muda. Bandung: Alfabeta, 2010.

Ulum, Misbahul dkk. (2007). ModelModel Kesejahteraan Sosial Islam: Prespektif Normatif, Filosofis dan Praktis. Yogyakarta: PT. LKIS Pelangi Aksara.

Ramadhan, Bagus Mohamad. (2015). Etos Kerja Islami Pada Kinerja Bisnis Pedagang Muslim Pasar Besar Kota Madiun. JESTT Vol. 2 No. 4. 274-287.

Sjafri, Sairin. (2002). Perubahan Sosial Masyarakat Indonesia. Yogyakarta: Pustaka Pelajar.

Sugiyono. (2012). Metode Penenelitian Kuantitatif, Kualitatif, dan $R n D$. Alfabeta Bandung 
Tasmara, Toto. (2002). Membudayakan Etos Kerja Islami. Jakarta: Gema Insani Press.

Widodo, Boby Hendra dan Febsry Susanti. (2019). Pengaruh Human Relation (Hubungan Antar Manusia), Lingkungan Kerja Terhadap Etos Kerja Karyawan (Studi Kasus Pada PT.Pelindo Teluk Bayur Padang). 